\title{
PKM KELOMPOK USAHA KECIL WARUNG MAKAN DI KAWASAN WISATA RELIGI BUKIT KASIH KANONANG KECAMATAN KAWANGKOAN KABUPATEN MINAHASA SULAWESI UTARA
}

\author{
Rahel Widiawati Kimbal \\ Fakultas Ekonomi, \\ Universitas Negeri Manado \\ rahelwk@unima.ac.id
}

\begin{abstract}
Abstrak
Keindahan Tempat Wisata Religi Bukit Kasih Kanonang sudah dikenal banyak kalangan. Maka tidak mengherankan dalam rentang Juni hingga Desember 2016 tercatat ada 35.028 wisatawan yang telah mendatangi objek wisata ini. Besarnya kunjungan ini telah mendorong lahirnya penawaran berbagai jasa. Salah satu kegiatan ekonomi yang dilakukan masyarakat adalah usaha kecil warung makan. Kelompok usaha kecil warung makan ini semuanya tidak memiliki latar belakang atau pendidikan formal. Kondisi ini menyiratkan bahwa kemampuan menjual yang berjalan antara pengunjung dengan penjual warung makan lebih bersifat natural. Pada kondisi ini mitra memiliki berbagai masalah seperti: (1) Terbatasnya kualitas pelayanan pemilik warung makan yang profesional. Hal ini ditandai dengan beberapa orang yang menggangap profesi ini hanya sebagai kerja sambilan biasa yang menyebabkan ketidakprofesionalan pelayanan. (2) Kurangnya pengetahuan dan keterampilan cara melayani yang benar dikarenakan para penjual makanan hanya melakukan sesuai pengalaman alami. Akibatnya layanan yang dihasilkan tidak semuanya memenuhi keinginan konsumen.

Metode dalam pelaksanaan kegiatan Program Kemitraan Masyarakat (PKM) ini melibatkan masyarakat khususnya penjual makanan pada warung kecil yang kurang memiliki pengetahuan dan keterampilan mengelolah usaha mereka. Selain itu, kegiatan Program Kemitraan Masyarakat (PKM) ini juga menggunakan pendekatan dengan cara melibatkan mahasiswa ekonomi sebagai pendamping dan sekaligus mereka belajar dan membagi ilmu. Kemitraan ini akan menguntungkan dalam menjamin keberhasilan dalam mengatasi permasalahan prioritas yang dialami oleh para pemilik warung makan di Bukit Kasih Kanonang.

Rencana kegiatan diawali dengan persiapan dengan pembahasan program dan langkah-langkah kerja yang akan dilaksanakan. Selanjutnya melakukan kordinasi dengan mitra untuk membahas serta mengindentifikasikan permasalahan mendasar yang harus segera diatasi. Kordinasi dengan mitra ini akan menghasilkan pemetaan informasi dan desain kegiatan yang diperlukan serta instrumen dan bentuk kegiatan baik berupa pelatihan maupun penerapan Program Kemitraan Masyarakat (PKM) yang tepat. Hasil yang didapatkan di lapangan adalah (1) Ada respons yang baik dari para Usaha Kecil Warung Makan sehingga mereka berpartisipasi dan hadir dalam kegiatan pengabdian kepada masyarakat (2) Terbentuknya pemahaman yang sama mengapa pengetahuan dan keterampilan menjadi sebuah kebutuhan bagi kegiatan pengelolaan dan pemasaran barang jualan, (3) Melalui kegiatan pengabdian pada masyarakat ini terjadi perubahan pola fikir (mindset) Usaha Kecil Warung Makan dalam hal pengetahuan dan keterampilan untuk mengelola dan memasarkan produk jualan dengan baik dan benar dan, (4) Meningkatnya pengetahuan dan keterampilan Usaha Kecil Warung Makan tentang cara memasarkan produk yang dipasarkan.
\end{abstract}

Kata Kunci: Kelompok usaha kecil warung makan, Bukit Kasih, Masyarakat 


\section{PENDAHULUAN}

Pada tahun 2002 lokasi pemandian air panas yang digunakan oleh masyarakat sebagai tempat untuk mengobati penyakit dan tempat wisata lokal. Akhirnya diubah menjadi lokasi wisata religi yang resmi namanya adalah Bukit Kasih Kanonang yang berkedudukan di Kecamatan Kawangkoan Kabupaten Minahasa Provinsi Sulawesi Utara. Pemberian nama ini diberikan oleh mantan Gubernur Sulawesi Utara yaitu Adolf Sondakh yang juga merupakan orang asli Kanonang. Pemberian nama ini dilatar belakangi oleh kata yang merupakan slogan pemerintah Sulawesi Utara berupa kata "torang samua basudara kong baku-baku bae deng baku-baku sayang. Artinya kita semua bersaudara, selalu berbaikan dan saling sayang menyayangi.

Kesempurnaan tempat wisata ini semakin indah dilengkapi dengan lima bangunan tempat ibadah agama-agama yang ada di Indonesia seperti: Kristen Protestan, Kristen Katolik, Islam, Hindu dan Budha. Selain itu di puncak tertinggi lokasi Bukit Kasih ini dibangun sebuah salib besar dengan tinggi 53 meter. Apabila pengunjung bisa mencapai salib tersebut. maka akan terlihat keindahan pemandangan daerah Kabupaten Minahasa dari Timur kebarat maupun utara ke selatan. Selain itu keindahan Bukit Kasih terlihat dengan adanya monumen yang bagian atasnya bergambar burung merpati dan bumi yang akan terlihat di awal memasuki lokasi Bukit kasih. Ada juga sumber air panas belerang yang dapat dijadikan masyarakat bahkan pengunjung sebagai tempat merebus jagung, ubi, telur, pisang dan lainlain.

Keindahan Tempat Wisata Religi Bukit Kasih ini semakin mempesona. Para pengunjung akan diperlihatkan dengan adanya tangga-tangga yang mengelilingi lokasi bukit Kasih yang terlihat seperti tembok cina. sarana rekreasi juga dilengkapi dengan kolam renang, lapangan tenis, lokasi bermain anak dan sarana lainnya. semua itu untuk memberikan kepuasan kepada pengunjung.

Kondisi ini menciptakan daya tarik tersendiri sebagai sebuah kawasan wisata. Pengunjung berdatangan ke Bukit Kasih. Ada yang berkunjung sekedar untuk menjawab rasa penasaran akan keberadaan keragaman tempat ibadah yang berdiri berjejer di atas bukit yang diselimuti asap yang menyembul dari sela-sela bukit belerang ataupun air panas yang gemericik mengalir. Ada pula yang mendatangi lokasi ini memang untuk tujuan melakukan ibadah bersama dengan memanfaatkan fasilitas kerohanian yang ada di Bukit Kasih baik berupa bangunan-bangunan maupun ruang terbuka yang memang sangat menarik. Keberadaan tangga yang terhampar memanjang dilereng bukit disertai pohonpohon pinus yang berdiri kokoh ditengah tandusnya bukit belerang. Umumnya pengunjung dengan tujuan serupa datang 
dalam bentuk rombongan atau kelompok. Kunjungan tersebut biasanya dilakukan dihari-hari libur nasional atau keagamaan.

Tidaklah mengherankan melihat orang berdatangan ke lokasi wisata ini. Menurut data Badan Pengelola Bukit Kasih melalui pusat informasinya disebutkan bahwa dalam rentang Juni hingga Desember 2015 tercatat ada 35.028 wisatawan yang telah mendatangi objek wisata ini dengan berbagai tujuan yang telah disebutkan diatas. Ini artinya ada animo yang cukup besar untuk mengunjungi Bukit kasih. Kondisi ekonomi yang mengalami pelemahan pada rentang tersebut didapati kunjungan wisatawan tetap berlangsung.

Besarnya kunjungan ini telah mendorong lahirnya penawaran berbagai jasa oleh warga yang berdomisili disekitar lokasi tersebut. Warga desa terdekat yakni penduduk Kanonang Raya Kecamatan Kawangkoan melirik potensi peningkatan pendapat dengan kehadiran para wisatawan/pengunjung dengan melakukan bermacam-macam kegiatan ekonomi.

Salah satu kegiatan ekonomi yang dilakukan masyarakat adalah profesi sebagai penjual makanan di warung kecil. Setiap pengunjung yang datang ke Bukit kasih akan ditawari makanan tradisional khas Bukit kasih. Seperti tinutuan, pisang goreng, jagung rebus dan bakar, mie cakalang, dan makanan khas lainnya. Hal ini tentu saja sangat membantu masyarakat dalam meningkatkan pendapatannya.
Apalagi pemilik warung makan ini umumnya adalah keluarga-keluarga yang sebagian besar hanya mengantungkan hasil pendapatan pada usaha ini. Kehadiran mereka di Bukit kasih sangat membantu ekonomi keluarga. Sehingga banyak diantara mereka yang menyekolakan anak mereka sampai perguruan tinggi dan ada beberapa anak yang bersekolah dan kuliah sambil melakoni profesi ini.

Dari data yang didapat pemilik usaha kecil warung makan yang beraktifitas di bukit kasih dapat di lihat pada tabel 1. berikut ini:

\begin{tabular}{|c|c|c|}
\hline No & Nama Desa & $\begin{array}{c}\text { Jumlah } \\
\text { Warung } \\
\text { Makan }\end{array}$ \\
\hline 1 & Kanonang 1 & 2 \\
\hline 2 & Kanonang 2 & 1 \\
\hline 3 & Kanonang 3 & 3 \\
\hline 4 & Kanonang 4 & 1 \\
\hline 5 & Kanonang 5 & 2 \\
\hline Total & & 9 \\
\hline
\end{tabular}

Tabel 1.

Penjual Asesoris di Bukit Kasih Kanonang

Sumber: Badan Pengelolah Bukit kasih (2018)

Daya tarik Bukit Kasih bukan hanya menarik minat wisatawan domestik tetapi juga wisatawan mancanegara. Gaung adanya sebuah tempat wisata yang menggabungkan antara pesan kebhinekaan dan fenomena alam yang ditandai dengan berdirinya tempat ibadah bagi agama resmi di Indonesia yang hanya dapat dijangkau dengan menaiki 2400 anak tangga dan keunikan sumber mata air panas yang mengalir dari lereng perbukitan disertai membumbungnya asap dari celah bebatuan 
telah menjadi pesona yang menghisap para wisatawan dalam dan luar negeri untuk datang berkunjung (kompas.com 12 april 2015). Ternyata daya tarik Bukit Kasih sekarang ini bukan lagi tugu toleransi atau 5 tempat ibadah yang dipuncak dan kurang terawat, tetapi lebih didominasi oleh "spa kaki" (pijat kaki) yang disediakan oleh para pemilik warung dengan menyediakan bakbak pemijatan baik di dalam warung maupun di luar warung di bawah payung besar (www.kompasiana.com 24 juni 2015)

Kedatangan wisatawan dalam dan luar negeri ini juga membawa peluang untuk mendapatkan pendapatan melalui jasa penjualan makanan tradisional di warung makan. Pikiran untuk mengais keuntungan dari pengunjung ini mendorong pemilik warung makan untuk menawarkan jasa mereka. Dengan bermodalkan keberanian ditambah sedikit nekad. warga setempat dapat berkomunikasi dengan para pengunjung. Dengan begitu saja, mereka sudah dapat menjual makanan khas mereka. Harga yang ditawarkan biasanya untuk tinutuan Rp.8000/piring, pisang goren Rp. 1000/biji, mie cakalang Rp.8000/piring, jagung rebus Rp. 3000/batang, nasi campur Rp20.000/piring dan masih banyak lagi makanan lokal khas yang ditawarkan oleh pemilik warung. Harga yang ditawarkanpun sangat terjangkau.

Dari catatan Badan Pengelola Bukit Kasih, ada sejumlah 8015 pengunjung yang berkunjung dalam rentang waktu Juni hingga Desember 2015. Jumlah yang cukup signifikan ini hanya dilayani oleh 9 (Sembilan) warung makan. Kelompok pemilik warung makan ini semuanya tidak memiliki latar belakang atau pendidikan formal yang berhubungan dengan teknik penjualan sebagai modal dasar. Kondisi ini menyiratkan bahwa kemampuan menjual dan melayani yang berjalan antara pengunjung dengan kelompok pemilik warung makan lebih bersifat natural.

Padahal apabila peluang kehadiran pengunjung yang umumnya datang dengan tujuan sepenuhnya untuk berwisata dan siap mengeluarkan uang untuk mengkonsumsi barang dan jasa-jasa yang sesuai harapan ini dijawab dengan profesionalisme para pemilik warung makan tradisional ini, maka potensi pendapatan yang lebih tinggi. Kualitas pelayanan dan menu makanan yang ditawarkan seringkali minim hanya sesuai kehendak pemilik warung makan. demikian halnya juga dengan variasi makanan yang ditawarkan sepertinya kurang variatif. Sehingga ketika pengunjung kembali berkunjung di bukit kasih. mereka akan menemukan makanan yang sama. Hal itu membuat para pengunjung mengurungkan niat untuk membeli makanan yang ditawarkan. Padahal setiap pengunjung berharap ketika berkunjung di bukit kasih. mereka akan merasakan manfaat ganda dari kunjungannya. Selain mata dipuaskan dengan keindahan alam Bukit Kasih, mereka 
juga akan mendapatkan makanan yang enak dan sehat ketika membeli makananl. Karena kebanyakan yang berwisata adalah orangorang yang fisiknya lelah. Jadi dibutuhkan makanan yang enak dan sehat. Oleh karena itu upaya peningkatan kemampuan menjual pada usaha warung makan ini akan sangat bermanfaat untuk menambah pendapatan para pemilik warung makan.

\section{Permasalahan Mitra}

Kompleksitas permasalahan yang muncul di atas melahirkan pemahaman bahwa tidak semua masalah tersebut dapat diatasi sekaligus. Oleh karena itu perlu dipilah dan dipilih masalah apa yang menjadi prioritas yang harus diselesaikan. Berdasarkan penilaian dan kesepakatan dengan mitra maka permasalahan yang harus diutamakan untuk diatasi antara lain:

1. Terbatasnya kualitas pelayanan pemilik warung makan yang profesional. Hal ini ditandai dengan beberapa pemilik warung yang menggangap profesi ini hanya sebagai kerja sambilan biasa yang menyebabkan ketidakprofesionalan. Permasalahan ini ironis mengingat sudah sepatutnya pemilik warung makan menjadikan usaha ini sebagai profesi andalan. Karena apabila dilakoni dengan baik akan memberikan kontribusi positif untuk peningkatan pendapatan keluarga. Misalnya teknik pelayanan yang variatif dan makanan khas yang sehat, enak dan berkualitas. Sehingga untuk meyakinkan konsumen dibutuhkan perjuangan lebih.
Kondisi ini disebabkan oleh tidak adanya upaya membenahi diri dan beberapa pemilik warung hanya menjadikan usaha ini hanya sebagai kerja sampingan.

2. Kurangnya pengetahuan dan keterampilan cara menjual dan melayani yang benar dikarenakan para pemilik warung makan tidak mendapatkan pelatihan khusus. Akibatnya layanan yang dihasilkan tidak semuanya memenuhi keinginan konsumen. Lemahnya pengetahuan dan keterampilan pemilik warung makan yang terbatas berdampak juga pada kurangnya konsumen mengkonsumsi makanan dalam warung makan. Berkaca dari pengalaman dan pelajaran pengembangan kawasan wisata yang maju diketahui bahwa potensi sekecil apapun dapat dijual kepada pengunjung dengan harapan akan menambah rasa keingintahuan dan keinginan untuk datang kembali. Seperti kawasan wisata yang telah maju di Pulau Jawa yang hampir semuanya disertai mitos-mitos tertentu misalnya Candi Prambanan dengan kisah Roro Jongrang, demikian juga mitos Toar Lumimuut yang terukir dilereng Bukit Kasih akan dapat dijual dengan makanan khas dengan menggunakan media air panas belerang untuk merebus jagung, pisang, ubi dll yang dapat menjadi kenangan indah 
ketika berkunjung di Bukit kasih kanonang.

Dalam konteks permasalahan di atas, didapati bahwa diperlukan upaya yang bukan hanya berupa penelitian tetapi penyebarluasan ilmu pengetahuan dan teknologi yang dikonkritkan dengan kegiatan pengabdian kepada masyarakat. Didorong oleh keinginan tersebut maka kami dari Universitas Negeri Manado melaksanakan kegiatan pengabdian kepada masyarakat sebagai upaya menerapkan Program Kemitraan Masyarakata (PKM) bagi masyarakat dengan tujuan untuk meningkatkan kualitas layanan, promosi dan manajemen dikawasan Bukit Kasih berupa pembenahan keterampilan dan pengetahuan sehingga dapat mendorong peningkatan pendapatan penduduk setempat sekaligus menarik minat serta peran generasi muda dalam pembangunan bangsa melalui partisipasi dalam pengembangan Bukit Kasih serta menjaga kesinambungan daya tarik dan eksistensi kawasan wisata tersebut.

\section{METODE PELAKSANAAN}

Keberhasilan suatu program ditentukan oleh tingkat partisipasi atau dapat diterima dan dirasakan manfaat kegiatannya oleh masyarakat luas. Oleh karena itu dalam pelaksanaan kegiatan Program Kemitraan Masyarakat (PKM) ini direncanakan melibatkan masyarakat khususnya pemilik warung makan tradisional yang kurang memiliki pengetahuan dan keterampilan mengelolah usaha mereka. Pemilik warung makan tradisional ini juga bersedia dihimpun dan membentuk kelompok pemilik warung makan tradisional yang belum pernah ada. Diharapkan kegiatan ini akan memberikan dampak yang lebih luas terutama dalam mengatasi permasalahan yang dihadapi pemilik warung makan tradisional saat ini. Di samping itu kegiatan ini akan melibatkan pemerintah desa dan tokoh agama atau adat setempat yang memiliki pengaruh kuat serta menjadi pribadi panutan dalam masyarakat.

Selain itu, kegiatan Program Kemitraan Masyarakat (PKM) ini juga menggunakan pendekatan lain yaitu dengan cara melibatkan pemilik warung makan profesional, pengusaha dan mahasiswa ekonomi sebagai pendamping dan sekaligus mereka belajar dan membagi ilmu dengan kegiatan magang dengan membagikan pengalaman belajar mereka di dalam kelas. Hal ini juga akan melahirkan jiwa wirausaha mahasiswa untuk menjadi wirausahawan melalui pengalaman praktis mengaplikasikan dan mengembangkan ilmu pengetahuan dan keterampilan yang didapat untuk membantu kelopok pemilik warung makan tradisional. Pada kegiatan PKM ini mereka akan berperan menjadi pendamping sekaligus tutor dan mitra latih bagi para pemilik warung makan tradisional yang mengikuti pelatihan ketrampilan mengelolah usaha. Kehadiran mereka akan 
memperkuat dan menyemangati partisipasi mitra kegiatan dalam hal ini kelompok pemilik warung makan tradisional. Kemitraan ini akan menguntungkan dalam menjamin keberhasilan dalam mengatasi permasalahan prioritas yang dialami oleh para pemilik warung makan tradisional di Bukit Kasih Kanonang.

\section{Rencana Langkah-Langkah Solusi yang Disepakati}

\section{Persiapan}

Persiapan merupakan langkah awal yang dilaksanakan oleh pelaksana pengabdian. Pada langkah ini pembahasan akan program dan langkah-langkah kerja yang akan dilaksanakan merupakan topik yang dibahas. Demikian juga aspek-aspek yang terkait dengan administrasi pelaksanaan setiap langkah-langkah. Hal ini diperlukan sebagai persiapan untuk evaluasi dan pelaporan pada akhir kegiatan. Tak kalah pentingnya dalam tahap ini adalah melakukan kordinasi dengan mitra untuk membahas serta mengindentifikasikan permasalahan mendasar yang harus segera diatasi. Kordinasi dengan mitra ini akan menghasilkan pemetaan informasi dan desain kegiatan yang diperlukan serta instrumen dan bentuk kegiatan baik berupa pelatihan maupun penerapan Program Kemitraan Masyarakat (PKM) yang tepat. Tingkatan penguasaan pengetahuan dan ketrampilan pengelolaan usaha penjual asesoris pun dilakukan pada tahap ini sebagai upaya untuk menyiapkan materi dan teknik penerapan serta fasilitas penunjang yang dapat secara efektif meningkatkan kemampuan para pemilik warung makan tradisional.

\section{Pelaksanaan Kegiatan}

\subsection{Sosialisasi}

Satu kegiatan yang sangat penting adalah sosialisasi. Kegiatan ini ditekankan pada pemberian pemahaman akan pentingnya kegiatan untuk meningkatkan pendapatan dan keberlanjutan Bukit Kasih sebagai ikon wisata serta untuk memastikan kepuasan para pengunjung. Pada proses sosialisasi ini, pemilik warung makan tradisional akan diberi gambaran bagaimana mitra dapat mengatasi masalah-masalah mendasar yang selama ini mereka hadapi. Hal ini penting untuk menumbuhkan kesadaran sejak awal bahwa kegiatan ini bukan semata-mata untuk kepentingan Tim Universitas Negeri Manado melainkan untuk menjawab kebutuhan mereka. Seperti dalam hal menjual jasa penjualan makanan yang tentu saja dapat memberikan keutungan tersendiri. Dengan begitu maka mitra akan mengambil tanggung jawab bersama untuk menjamin keberhasilan pelaksanaan kegiatan pengabdian sekaligus melihat bahwa kegiatan ini tak bisa diabaikan. Kesadaran ini akan berperan penting untuk menentukan keberhasilan pelaksanaan kegiatan Program Kemitraan Masyarakat (PKM) 


\subsection{Proses Pelatihan}

Pelaksanaan kegiatan ini langsung memadukan teori dan praktek dalam setiap pertemuannya. Ini berarti bahwa pemilik warung makan tradisional sebagai mitra akan langsung dilibatkan dalam praktek menjual sambil diselingi pemberian teori yang sesuai dengan konteks dan tujuan pengelolaan usaha pemilik warung makan tradisional. Dengan demikian pelatihan ini menjadi proses pembelajaran teori ekonomi sekaligus penerapannya. Pada titik ini peran pelibatan komunitas belajar menjadi terasa sangat bermanfaat sebab mereka akan bermain peran (role play) untuk menjadi model dan pada giliran berikutnya menjadi partner latih bagi para pemijat tradisional yang mengikuti kegiatan pelatihan. Dilain waktu, komunitas belajar dapat menjadi tempat bertanya untuk aspek pengetahuan atau teoretis yang belum dipahami. Hal ini sangat membantu peran tim pelaksana sekaligus bisa membuka jalan keberhasilan bagi pelaksanaan keseluruhan kegiatan. Dalam kaitan itu dapat ringkas bahwa implementasi yang dilaksanakan untuk menjadi solusi permasalahan sebagai berikut.

Pertama, memberikan pemahaman khusus kepada pemilik warung makan dengan menjadikan profesi ini sebagai profesi utama yang perlu ditekuni karena pekerjaan ini memiliki konsumen dan pasar yang cukup besar. Pemahaman ini di dapat melalui transfer ilmu yang diberikan melalui pelatihan dengan memberikan 1) pemahaman betapa pentingnya sebuah pekerjaan yang dilakoni secara profesional. 2) mempelajari keunikan makanan tradisional Bukit Kasih dengan sebagaian produk makanannya menggunakan media air belerang dengan memunculkan ceritacerita rakyat berupa gambar salib, monument Bukit Kasih, patung Toar Lumimuut yang merupakan nenek moyang orang minahasa dan hal unik lain yang memiliki karakter mengenai Bukit Kasih. 3) bekerjasama dengan pemilik warung makan profesional dengan memberikan pelatihan dan keterampilan cara menjual dan melayani pengunjung yang makan di warung. 4) pemahaman kepada mitra dengan tetap menjaga kualitas makanan yang dihasilkan.

Kedua, pengetahuan dan keterampilan dalam hal mengelola usaha jasa pemilik warung makan tradisioanl. Para pemilik warung makan tradisional diberikan teori dan latihan mengenai cara mengelola usaha ini. mulai dari teknik mengelolah makanan yang benar yang hendaknya diketahui kualitas makanan yang ditawarkan kepada konsumen. Hal ini akan membantu mereka menjual makanan dengan mengikutsertakan cerita-cerita mengenai Bukit Kasih yang memiliki sejarah khusus bagi masyarakat Minahasa. Tambahan cerita rakyat mereka akan menjadi daya tarik sendiri yang membuat pengujung merasa puas yang tentu saja 
secara spontan akan ikut menikmati makanan khas yang disugukan. Selanjutnya mitra usaha hendaknya menggunakan bahasa yang tepat dan mudah dimengerti oleh pegunjung tanpa membuat kesalahan berkomunikasi. Serta ikut menciptakan suasana akrab yang membuat pengunjung betah dan akan berlama-lama menikmati keindahan alam Bukit kasih sambil menikmati makanan di alam terbuka.

\section{HASIL DAN PEMBAHASAN}

Program Kemitraan Masyarakat (PKM) ini dilaksanakan kepada kelompok Usaha Kecil Warung Makan yang merupakan mitra dalam kegiatan ini. Mitra dalam kegiatan ini berjumlah 9 orang dan mereka memiliki jenjang pendidikan yang berbeda-beda seperti SD, SMP dan SMA.

Persoalan kelompok Usaha Kecil Warung Makan ini sebagai mitra terletak pada 2 hal yaitu : (1) Terbatasnya kualitas pelayanan pemilik warung makan yang profesional. Hal ini ditandai dengan beberapa orang yang mengangap profesi ini hanya sebagai kerja sambilan biasa yang menyebabkan ketidakprofesionalan dalam pelayanan yang diberikan artinya hanya asal-asalan tanpa memperhatikan bagiabagian penting misalnya kebersihan, wadah pemberian makanan, alat makan yang disajikan, lingkungan sekitar dan lain sebagainya. (2) Kurangnya pengetahuan dan keterampilan cara melayani yang benar dikarenakan para penjual makanan hanya melakukan sesuai pengalaman alami. Mereka tidak memiliki pengetahuan khusus misalnya cara berpakaian yang sopan dan bersih, cara bertutur kata, cara melatakkan makanan dan konsistensi dalam pelayanan yang berubah-ubah. Akibatnya layanan yang dihasilkan tidak semuanya memenuhi keinginan konsumen. Selanjutnya status sosial kelompok Usaha Kecil Warung Makan ini bervariasi. Ada yang bekerja sebagai petani, pedagang, ibu rumah tangga, dan lain-lain.

Lokasi PKM dari perguruan tinggi adalah $30 \mathrm{Km}$ dengan sarana transportasi yang digunakan adalah angkutan umum, mobil dan sepeda motor. Sarana komunikasi yang digunakan berupa telepon, internet dan surat. Untuk tim PKM berjumlah 2 (dua) dosen yang bergelar doktor dengan 5 (lima) orang mahasiswa.

Untuk metode pelaksanaan kegiatan yaitu pertama, memberikan pemahaman khusus kepada penjual warung makan dengan menjadikan profesi ini sebagai profesi utama yang perlu ditekuni karena pekerjaan ini memiliki konsumen dan pasar yang cukup besar dan kedua, adalah memberikan pengetahuan dan keterampilan cara menjual makanan yang benar sesuai dengan kebutuhan konsumen. Sehingga hasil jualan akan berdampak positif bagi kesehatan konsumen.

Pertama, permasalahan yang sangat mendasar yakni terkait dengan bagaimana strategi untuk meningkatkan 
kualitas jasa pelayanan dan variasi makan sehat dan berkualitas. Sehingga dapat menjawab harapan dan keinginan dari para pengunjung di Bukit Kasih Kanonang. Hal ini dapat dilaksanakan dengan memberikan pemahaman khusus kepada pemilik warung makan dengan menjadikan profesi ini sebagai profesi utama yang perlu ditekuni karena pekerjaan ini memiliki konsumen dan pasar yang cukup besar. Hal ini tentu saja membutuhkan kerjasama dengan pemilik warung makan yang profesional dan sudah berhasil dan menjalankan usahanya sekian tahun. Seperti para pemilik warung makan dapat mengetahui dasar dari kualitas layanan makanan yang disajikan dengan mengetahui bahan yang digunakan, lamanya waktu proses masak, dan menu apa saja yang banyak diminati oleh konsumen. Kegiatan pengenalan ini hendaknya dilakukan berjenjang sampai pemilik warung Bukit Kasih dan pemilik warung profesional dan berhasil dapat memiliki hubungan kerjasama yang saling menguntungkan satu dengan yang lainnya. Dengan kata lain, luaran dari strategi ini akan terlihat pada peningkatan penguasaan kemampuan menjelaskan secara mendetail mengenai teknik menjual dan melayani yang benar. harapannya informasi yang mendetail mampu memberikan daya tarik tersendiri pada konsumen untuk dapat menggunakan pelayanan dengan mendapatkan kepuasan maksimal. hal ini tentu saja menjadi nilai tambah untuk kemajuan usaha warung makan di Bukit Kasih Kanonang.

Selanjutnya permasalahan kedua adalah memberikan pengetahuan dan keterampilan cara menjual dan melayani yang benar sesuai dengan kebutuhan konsumen. Sehingga hasil pelayanan dan makanan akan berdampak positif bagi kesehatan konsumen. Hasil penjualan yang tidak variasi dan menu yang asal-asalan hendaknya dibuat lebih bervariasi sesuai kebutuhan konsumen. Sehingga konsumen akan merasakan manfaat dari makanan yang dikonsumsi tersebut. Hal lain yang menjadi nilai tambah adalah pemilik warung makan dalam melakukan aktifitasnya menggunakan air panas belerang sebagai media merebus salah beberapa makanan khas. Pemandangan menarik ini membuat nafsu makan pengunjung bertambah. Karena hasil rebusan air belerang tersebut rasanya khas dan mengenakan. Hendaknya pemilik warung ketika melayani orang dia akan berbagi cerita mengenai keberadaan Bukit Kasih kanonang beserta dengan sejarah yang ada. Hal ini sangat menarik karena cerita tersebut merupakan hiburan sekaligus informasi yang dapat membuat konsumen merasakan energi baru yang membuat mereka bersemangat untuk tetap menikamti alam semesta dengan bersyukur kepada Tuhan. Cerita rakyat dari setiap patung toar lumimuut, air panas belerang, tugu perdamaian, anak tangga sampai 
ribuan dan lima tempat ibadah merupakan bahan cerita menarik dari pemilik warung makan untuk dibagikan kepada konsumen. Hal ini akan merangsang para konsumen untuk menggunakan jasa pemilik warung makan, bahkan akan menggingat terus cerita tersebut sampai mereka kembali ke tempat asal mereka. Kepuasan yang didapat seperti kebanggaan pernah mengunjungi bukit kasih dengan menikmati makanan khas rebusan di media air panas belerang. Tentu saja solusi ini akan berdampak pada daya tarik wisata yang telah mendapat sentuhan penerapan Program Kemitraan Masyarakat (PKM).memberikan sentuhan keilmuan berupa pemberian pelatihan keterampilan cara memijat dengan belajar mengenal lebih dekat karakter orang yang berbeda dalam memijat. dan kedua, adalah, variasi pijatan yang monoton hendaknya dikembangkan menjadi lebih kaya dengan memasukkan unsur budaya bukit kasih. Maka perlu adanya kerjasama dengan Usaha Kecil Warung Makan pendahulu dengan mengkomunikasikan cara pijatan terbaru terbaru untuk diciptakan. sehingga ada penyegaran kembali variasi pijatan.

Luaran kegiatan PKM ini antara lain: (1) Peningkatan jumlah Usaha Kecil Warung Makan handal yang memiliki keterampilan dan pengetahuan khusus pada bidang pengelolaan usaha pijatan di Bukit Kasih. (2) Terciptanya variasi pijatan baru yang memiliki kualitas tinggi serta berkarakter Bukit Kasih Kanonang.

Metode dalam pelaksanaan kegiatan Program Kemitraan Masyarakat (PKM) ini melibatkan masyarakat khususnya Usaha Kecil Warung Makan yang kurang memiliki pengetahuan dan keterampilan mengelolah usaha mereka. Usaha Kecil Warung Makan ini juga bersedia dihimpun dan membentuk kelompok yang belum pernah ada. Diharapkan kegiatan ini akan memberikan dampak dalam mengatasi permasalahan yang dihadapi Usaha Kecil Warung Makan. Di samping itu kegiatan ini akan melibatkan pemerintah desa dan tokoh agama atau adat setempat yang memiliki pengaruh kuat serta menjadi pribadi panutan dalam masyarakat.

Selain itu, kegiatan Program Kemitraan Masyarakat (PKM) ini juga menggunakan pendekatan dengan cara melibatkan mahasiswa ekonomi sebagai pendamping dan sekaligus mereka belajar dan membagi ilmu. Kemitraan ini akan menguntungkan dalam menjamin keberhasilan dalam mengatasi permasalahan prioritas yang dialami oleh para Usaha Kecil Warung Makan di Bukit Kasih Kanonang.

Melalui kegiatan ini dapat dicapai beberapa hal seperti:

(1) Ada respons yang baik dari para Usaha Kecil Warung Makan sehingga mereka berpartisipasi dan hadir dalam kegiatan pengabdian kepada 
masyarakat. Para Usaha Kecil Warung Makan ketika mendapatkan undangan dari Tim pengabdian sangat antusias untuk mengikuti kegiatan ini. Hal ini dibuktikan dengan kehadiran mereka yang tepat waktu. Bukan itu saja, kehadiran mereka menandakan besarnya harapan untuk mendapatkan pengetahuan mengenai cara memijat yang baik dan mengelolah usaha mereka.

(2) Terbentuknya pemahaman yang sama mengapa pengetahuan dan keterampilan menjadi sebuah kebutuhan bagi kegiatan pengelolaan dan pemasaran jasa Usaha Kecil Warung Makan. Ketika mengikuti kegiatan ini, para Usaha Kecil Warung Makan menjadi sadar ternyata kegiatan pengelolaan dan pemasaran jasa pijat ini sangat penting dalam usaha kegiatan mereka. Hal ini dinyatakan oleh salah satu Usaha Kecil Warung Makan yaitu Ibu Santi Ratu yang mengatakan bahwa selama ini mereka hanya bermodalkan kenekatan ketika menjual jasa pijatan. Mereka hanya memiliki bekal pengetahuan alami yang datang dari diri mereka sendiri. Sehingga kemampuan mereka memijat berdasarkan keaktifan pribadi lepas pribadi.

(3) Melalui kegiatan pengabdian pada masyarakat ini terjadi perubahan pola fikir (mindset) Usaha Kecil Warung
Makan dalam hal pengetahuan dan keterampilan untuk mengelola dan memasarkan keahlian mereka dengan baik dan benar. Terbentuknya pola pikir yang baik dan benar dalam menjual jasa pijatan tradisional di lokasi wisata Bukit kasih kanonang, tentu saja menjadi input positif buat masyarakat setempat dan khususnya para Usaha Kecil Warung Makan. Karena selama ini mereka hanya berpikir menjual dan jasa mereka dibeli oleh para pengunjung. Itulah tujuan utama mereka dan setelah itu memperoleh keuntungan. Seperti yang dituturkan oleh salah satu penjual ibu Detty Warangkiran yang menyatakan bahwa ketika mereka menjual jasa asesoris kepada pengunjung, mereka mengikuti dari belakang dan seakanakan terus menerus mengikuti pengunjung. Mereka akan berhenti ketika para pengunjung sudah membeli jasa mereka. Hal lain lagi mereka tidak pernah memikirkan perasaan pengunjung apakah mereka nyaman atau tidak dengan kehadiran para Usaha Kecil Warung Makan. Hal itulah yang membuat beberapa pengunjung mengeluarkan kata menolak dengan kasar ketika ditawarkan jasa pijatan tersebut. Sebagai penjual hal itu adalah hal yang biasa. Bagi mereka Usaha Kecil Warung Makan yang penting jasa pijatan mereka laku dibeli. Setelah 
mengikuti kegiatan ini para Usaha Kecil Warung Makan mulai mendapatkan pengetahuan bagaimana keberadaan mereka dapat diterima oleh pengunjung tanpa menggangu kenyamanan pengunjung. Hal yang dilakukan adalah mereka akan memberikan informasi tentang keberadaan bukit kasih dengan menuangkan sejarah bukit kasih yang cukup menarik mengenai cerita dari setiap patung yang ada. Misalnya patung Toar Lumimuut yang merupakan nenek moyang orang Minahasa. Begitu juga dengan adanya patung salib dan bangunan

(4) Rumah ibadah. Cerita ini dapat membantu pengunjung untuk menikmati keindahan wisata Bukit Kasih ini. Tentu saja secara otomatis mereka akan membeli asesoris meskipun tidak ditawarkan. Selanjutnya ketika barang mereka akan dibeli, para Usaha Kecil Warung Makan akan menjelaskan beberapa arti dibalik kegiatan pijatan menereka. Contohnya salib artinya adalah sebuah pengorbanan serta arti-arti lain yang tergambar dalam beberapa asesoris tersebut.

(5) Meningkatnya pengetahuan dan keterampilan Usaha Kecil Warung Makan tentang cara memasarkan jasa pijatan agar terus meningkat, cara memelihara hubungan antara konsumen dan produsen. Selanjutnya cara membangun hubungan berkelanjutan dengan konsumen agar tetap bertahan bukan hanya sekedar jual beli saja. Awalnya hal ini kurang disadari oleh para Usaha Kecil Warung Makan. Mereka hanya berpikir klasik yaitu ketika jasa mereka dibeli orang maka hubungan mereka selesai ketika terjadi transaksi jual beli. Selama ini mereka tidak berpikir bahwa hubungan ini harus tetap dijaga meskipun pengunjung baru sekali datang mengunjungi. Mereka tidak berpikir bahwa pengunjung itu memiliki keinginan untuk kembali datang mengunjungi Bukit kasih, dengan membawa teman-teman mereka ataupun sendiri untuk kembali menikmati keindahan Lokasi wisata ini. Setelah mengikuti kegiatan ini para Usaha Kecil Warung Makan sadar ternyata hubungan yang berkelanjutan sangat penting dalam kegiatan usaha mereka. Sebab apa yang mereka lakukan selama ini ternyata dapat memperpendek usaha mereka. Oleh sebab itu memelihara hubungan dengan memberikan produk yang berkualitas sangat penting. Bukan itu saja pemberian bonus harga ikut membantu kelangsungan hubungan ini. Hal ini perlu diterapkan agar usaha ini tetap hidup dan berkelanjutan. 


\section{KESIMPULAN DAN SARAN}

\section{Kesimpulan}

Melalui kegiatan Pengabdian pada masyarakat maka dapat disimpulkan:

(1) Ada respons yang baik dari para Usaha Kecil Warung Makan sehingga mereka berpartisipasi dan hadir dalam kegiatan pengabdian kepada masyarakat

(2) Terbentuknya pemahaman yang sama mengapa pengetahuan dan keterampilan menjadi sebuah kebutuhan bagi kegiatan pengelolaan dan pemasaran produk di warung kecil

(3) Melalui kegiatan pengabdian pada masyarakat ini terjadi perubahan pola fikir (mindset) Usaha Kecil Warung Makan dalam hal pengetahuan dan keterampilan untuk mengelola dan memasarkan barang dengan baik dan benar dan,

(4) Meningkatnya pengetahuan dan keterampilan Usaha Kecil Warung Makan tentang cara memasarkan barang jualan agar terus meningkat, cara memelihara hubungan antara konsumen dan produsen.

\section{Saran}

1. Masyarakat mengharapkan kegiatan ini kembali dilaksanakan secara berkesinambungan agar dapat memberikan nilai tambah dalam usaha penjualan warung kecil.

2. Usaha Kecil Warung Makan mengharapkan mereka bisa bekerjasama dengan pemerintah dan membentuk sebuahkelompok yang mampu mengatur kegiatan mereka sehingga kegiatan mereka teratur dengan penjualan usaha warung kecil.

3. Pihak Universitas Negeri Manado dan pemerintah setempat dapat bekerjasama aktif untuk melahirkan Usaha Kecil Warung Makan baru yang memilik keterampilan dan pengetahuan yang unggul.

\section{KEPUSTAKAAN}

Faig, H. Salam Damai Dari Bukit kasih. travel.kompas.com 12 April 2015.

Lokon, T. Menikmati Lokalisasi Pijat Kaki di Bukit Kasih Kasih Kanonang. www.kompasiana.com 24 Juni 2015.

Ikanubun, Y. Tugu Kerukunan dan Pagi di Bukit Kasih Kanonang. Regional.liputan6.com 4 Juli 2017.

Kuncoro,M. 1997. Ekonomi Industri, Teori Kebijakan dan Studi Empiris di Inonesia. Widya Sarana Informatika. Yogyakarta.

Maulana, A. 1987. Manajemen pemasaran. Erlangga. Jakarta

Maskun, S. 1993. Pembangunan Masyarakat Desa Asas, Kebijaksanaan dan Manajemen. Media Widya Mandala. Yogyakarta.

www.bulawanews.com. Mau Pijat Air Panas Belerang. 3 Juni 2017.

Perry, M. 2000. Mengembangkan Usaha Kecil Dengan Memanfaatkan Berbagai Bentuk Jaringan Kerja Ekonomi. PT raja Grafindo Persada. Jakarta

Soebagyo. 2012. Strategi Pengembangan Pariwisata di Indonesia. Jurnal of Liquidity, vol 1, no 2 Juli-Desember. hlm 153-158 